\title{
AsSessing the Quality Of Persian Translation OF OrWell's NINETEEN EIGHTY-FOUR BASED ON HOUSE'S MODEL: OVERT-COVERT TranSLATION DISTINCTION
}

\author{
Hossein Heidari TABRIZI \\ Islamic Azad University \\ heidaritabrizi@gmail.com
}

\author{
Azizeh CHALAK \\ Islamic Azad University \\ azizeh_chalak@yahoo.com
}

\author{
Amir Hossein TAHERIOUN \\ Islamic Azad University \\ ataherioun@gmail.com
}

\begin{abstract}
This study aimed to assess the quality of Persian translation of Orwell's (1949) Nineteen EightyFour by Balooch (2004) based on House's (1997) model of translation quality assessment. To do so, about 10 percent of the source text was randomly selected. The profile of the source text register was produced and the genre was realized. The source text profile was compared to the translation text profile. The result of this comparison was dimensional mismatches and overt errors. The dimensional mismatches were categorized based on different dimensions of register. The overt errors which were based on denotative mismatches and target system errors were categorized into omissions, additions, substitutions, and breaches of the target language system. Then, the frequencies of occurrences of subcategories of overt errors along with their percentages were calculated. The dimensional mismatches and a large number of major overt errors including omissions and substitutions indicated that the translation was not in accordance with the House's view stating that literary works needed to be translated overtly. Mismatches on different levels of register showed that the cultural filter was applied in translation and the second-level functional equivalence required for overt translation was not reached. Therefore, the Persian translation of Nineteen Eighty-Four did not fulfill the criteria to be an overt translation.
\end{abstract}

Keywords: translation; quality; assessment; House; Nineteen Eighty-Four; Orwell

Acta Linguistica Asiatica, 4(3), 2014.

ISSN: 2232-3317, http://revije.ff.uni-lj.si/ala/

DOI: 10.4312/ala.4.3.29-42 


\section{Povzetek}

Cilj študije je po House-ovem modelu oceniti kvaliteto prevoda Orwellovega Nineteen EightyFour (1949), ki ga je v perzijščino leta 2004 prevedel Balooch. Iz omenjenega dela je bilo naključno izbranega približno deset odstotkov teksta, iz katerega smo naredili profil izvornega besedila, ki je bil kasneje primerjan s profilom prevedenega besedila. Razultati so nakazali na dimenzijska neskladja in vidne napake. Dimenzijske neskladja so bila kategorizirana na osnovi različnih dimenzij registra. Vidne napake, ki so predvsem posledica denotativnega neskladja ali napak v ciljnem sistemu, so bile najpogosteje definirane kot opustitve, dopolnitve, zamenjave ali kršitve sistema ciljnega jezika. Podkategorije vidnih napak so bile analizirane statistično in za vsako podkategorijo podan je odstotek pojavitve. Tako dimenzijska neskladja kot tudi veliko številko osnovnih vidnih napak nakazujejo, da prevod ni v skladu s House-ovo idejo o odkritem prevajanju literarnih del. Neskladja na različnih nivojih registra kažejo na to, da je bil prevod kulturno prilagojen, zato ni izpolnil pogojev funkcijske primerljivosti in s tem t.i. odkritega prevoda.

Ključne besede: prevod; kvaliteta; ocena; House; Nineteen Eighty-Four; Orwell

\section{Introduction}

According to Williams (2004), concern for excellence in translation, especially translation of literary and religious works, has existed for long time. There have been discussions, debates, and approaches about quality of translation and how good a translation of a text should be. Translators, translation companies and translation services of governments and international organizations must all be accountable for the quality of their product. Yet the question of how to judge that quality can be very difficult. This judgment is different from a person to another and it depends on type of the text. The serious issue is concerning the quality of translation of literary works. Every community has its own specific culture, traditions, and language with different structures. Consequently, every source text has its own linguistic, semantic, and pragmatic structures that can be different from those of target text. Thus, bearing this in mind, the translator should take a specific strategy to transfer intended meaning and structure of the original text into target text. Failing to recognize the structure of source text and the way of rendering the structure into target language affects the quality of translation. In Iran, there are translations especially in the field of literature that have low quality. It can be due to the fact Iranian translators are less familiar with or less interested in the translation quality and the criteria and standards by which translation should be evaluated. There should be reliable criteria and standards by which translation can be assessed and evaluated. These criteria and standards can work properly on the basis of a framework or a model. They differentiate a good translation from a bad one. They provide valuable information in which the translator's failure and mistakes in translation process are identified. This can help translators improve their performance by knowing their weaknesses and mistakes and as a result, the quality of the translation is enhanced. There are different models and approaches for assessing the quality of translation. One of them is House's (1997) model of translation quality assessment (TQA) which covers 
almost all aspects in process of translation and has some advantages over other models due to its coverage issue and the easiness of use.

Several researchers used House's (1997) model to analyze the quality of translation of literary works. Mohebbipour (2010) in his article assessed the quality of Persian translation of Faulkner's The Sound and the Fury. He focused on distinction between overt and covert translation and stated that according to House, to translate literary works such as The Sound and the Fury the overt kind of translation needed to be applied. Then, for analysis of the text, he defined overt errors and covert errors and provided some Persian translation examples with their transcriptions for overt errors. Mohebbipour also provided word for word translation for errors that he found in translation. He calculated the frequency of the occurrences of errors and finally he used Chi-square to analyze the results of the study. By comparing ST profile with the TT one, only one mismatch in the tenor was found. There were also instances of overt errors such as wrong translation, omissions, additions, and wrong combination of elements in the translation. The researcher claimed that the translator had a good knowledge of TL syntax because there was no evidence of breach of TL system. Computing the frequency of errors through Chi-square, the result showed the statistically significant difference between two overtly and covert errors as well as the statistically significant difference among subcategories of overt errors. Gehrmann (2011) used the TQA model proposed by House (1997) to assess Swedish translation of Tolkien's The Lord of the Rings. The main work of the research was to provide the textual profiles of both ST and TT. By analyzing the profiles of the two texts, a number of mismatches on the dimensions of tenor and field were found. There were also overt errors caused by the semantic additions. The additions on the dimension of field caused a greater explicitness in the translation and increased aesthetic pleasure for the audience. However, this manipulated the readers' interpretation and imagination and as a result, the interpersonal function. The social attitude was changed on the dimension of tenor because the level of style becomes more literary by addition of qualifying adverbials. No errors were found on the dimensions of genre and tenor. Based on the translator's view about the translation in which translation was to be like an original of TT, Gehrmann concluded that the translation of The Lord of the Rings was a covert kind of translation.

The purpose of this research was to assess the quality of Persian translation of Orwell's (1949) Nineteen Eighty-Four by Balooch (2004) based on House's (1997) model of translation quality assessment (TQA). By using House's model, the translation strategies used by the translator became known. House mentions two types of strategies known as overt translation strategy and covert translation strategy that translators can use based on different types of texts. Distinction between overt translation and covert translation revealed the errors and mistakes made during the translation process as well as mismatches between ST and TT. Based on House's model of TQA, there are two main sources of errors in translation: (a) overt errors and (b) covert errors. Significance of overt errors in this study leaded the evaluation process into computing the frequency of occurrences of these errors in order to see whether a significant difference existed 
between ST and TT based on House's distinction between overt and covert translation. Based on analysis of findings of the study, the following questions could be answered:

1. Which strategies has the translator most frequently used for translating Orwell's (1949) Nineteen Eighty-Four based on House's (1997) model of translation quality assessment?

2. To what extent has the quality of Persian translation of Orwell's Nineteen Eighty-Four been preserved based on House's model?

\section{Methodology}

\subsection{Participants}

The researcher of this study was taken as the participant, since he selected materials and analyzed the data. However, for the matter of inter-rater reliability, another participant who was an MA student of English Translation was selected to study and to analyze the same extracted materials with the same theoretical framework. The purpose was replication of the research in the identical situations in order to see whether the same results were achieved or not.

\subsection{Materials}

For the purposes of this study, Orwell's (1949) Nineteen Eighty-Four was chosen as the case study. It is a classic novel which has influenced contemporary literature and some other artistic works such as popular music and movies. This book is considered as a dystopian science fiction containing several neologisms such as Big Brother, doublethink, and Thought Police. Some of these neologisms have been brought into language and become contemporary vernacular. The popularity and the fame of Nineteen Eighty-Four were the other reasons to choose this book as the case study. Since this study was a descriptive-comparative analysis of a translation by means of House's (1997) model of TQA, the materials consisted of Nineteen Eighty-Four and its Persian translation by Balooch (2004). Without considering the front matter and the appendix, Nineteen Eighty-Four has totally 234 pages (from page 5 to page 239) divided into three parts. In fact, the analysis of the whole book and comparing it with its Persian translation would have taken too much time. Moreover, specific features of the novel such as its language, characters, and style did not belong to certain parts of the text but they were distributed all over the text. Considering the above mentioned reasons, a systematic random sampling method was used to collect the data. Based on this method 10 percent of the book (about 23 pages) was selected as the sample. To find the frequency interval, 234 was divided by 23 ; the result was 10 . Every $10^{\text {th }}$ page of the book (source text) 
included the pages of $15,25,35,45,55,65,75,85,95,105,115,125,135,145,155$, $165,175,185,195,205,215,225$, and 235 based on which the text analysis was performed and compared with the TT.

\subsection{Theoretical Framework}

House's (1997) model of translation quality assessment was used as a theoretical framework for this research. Unlike some other models which consider the text consisting of separate elements, House's model takes the text as a whole phenomenon. The model is functional and encompasses different dimensions of text such as linguistic, pragmatic and discourse. House's (1997) model involves textual and register analysis of profiles of both the source and target text. Register analysis of ST and TT profile can be realized via lexical, syntactic, and textual means. Textual means comprises themedynamics, clausal linkage, and iconic linkage. The model operates at different levels of analysis. It begins from the level of 'individual textual function'; then, goes to the levels of register and genre; and finally ends at the level of 'language/text'. The level of register analysis covers three dimensions of field, tenor, and mode. Field refers to analysis of subject matter and social action. Tenor covers participant relationship including author's provenance and stance, social role relationship and social attitude. Mode refers to channel or medium of communication and participation in the text. Comparing ST profile with TT profile bring about mismatches between the two profiles. Dimensional errors and mismatches are referred to as covert errors, whereas, mismatches of the denotative meanings or breaches of target language system are overt errors. House also presumes two kinds of translation, namely as covert and overt translation. A covert translation is a translation that appears as if it produces in the target culture. On the other hand, an overt translation is a translation that the cultural features of the source text are purposefully retained. After analysis of ST, TT, mismatches and errors, the translation can be recognized as either covert or overt one. While overt translation and its original text need to be matched at the levels of genre, register, and language/text, in covert translation only genre and the primary level function have to be matched with the original text. It is worth mentioning that according to House, overt translation is suitable for the texts such as literary works, fictions, moral anecdotes, comedy dialogues, and historic speeches, while covert translation covers text types including scientific texts, tourist information booklets, economic texts, journalistic texts, and advertisements.

\subsection{Procedures}

At first, based on House's (1997) model, the ST was analyzed and its profile including the register was obtained. Based on register analysis of ST, ST genre was realized. Then, a statement of function was made for the source text. Then, the same steps were taken for the TT, that is, TT profile was obtained. The TT profile was analyzed and compared with the ST profile. The results were mismatches and errors including lexical, syntactic, textual mismatches. They categorized into two groups of 
covert errors and overt errors. The frequency of occurrences of the overt errors was calculated. It should be mentioned that the unit of errors recognized in the study was phrase. Each phrase contained one or more errors. Every single error was taken into account in the process of calculation of the frequency of occurrences. Each error and mismatch was provided with a description and an example from ST and TT. A statement of quality was made based on the results of analysis ST and TT. Finally, the type of translation was recognized based House's distinction between overt and covert translation.

Since this study was based on House's (1997) model and this model was a nonquantitative and descriptive-explanatory one, a non-statistical and descriptive method was used in order to analyze the data. By comparing the randomly selected parts of the source text with their Persian counterparts in the translated text, some mismatches and errors were revealed. The dimensional errors were referred to as covert errors; while, those errors related to denotative mismatches or target system errors were referred to as overt errors. Because of significance role of overt errors in translation quality assessment of literary translations, the frequency of occurrences of overt errors and their percentages were computed. House suggests overt kind of translation for literary works. Therefore, the translation was assessed against the criteria and characteristics that an overt translation needed to have. In other words, the ST and TT profiles were analyzed to see whether the second level functional equivalence was achieved and consequently, whether at this level the target text matched genre, register, text and linguistic strategies of the source text. If these criteria were fulfilled, the translation would be assumed as an overt kind of translation. On the contrary, if the translation did not match with the source text on dimensions of register and language/text and instead, applied a cultural filter, then, the translation could be assumed as a covert kind of translation.

\section{Findings}

\subsection{Source Text (ST) Profile}

To describe the dimension of FIELD, it should be said that Nineteen Eighty-Four is a dystopian novel. It is a classic novel which is very famous and popular among other literary works. The story is designed to be read by adults. Lexical means applied on field were use of neologisms such as Big Brother, doublethink, and Thought Police, use of no technical academic terms, presence of several collocations and idioms such as p. 15 act a part; p. 105 the coast is clear; and instances of informal words like damn and negroid. The story mostly contained short simple clauses and sentences. However, there were several instances of long sentences consisted of short subordinate clauses and phrases. Orwell (1949) often used the punctuations such as semicolon, colon, and comma within 
the text. The author often began the sentences with adverbs, conjunctions, and relative pronouns: p. 25 what he had written ...; and p. 85 Then he went.... Strong cohesion was achieved through repetitions and iconic linkage: p. 65 and then, for..., and then $a$ voice...; p. 135 if I confess..., if I refuse.... There were also theme dynamics especially sequences of theme-rheme, anaphoric referencing by means of pro-forms for noun phrases, adverbials, clauses or sentences, and instances of clausal linkage: when, as, but, and, that is, therefore. On TENOR, author's temporal, geographical and social provenance was unmarked, contemporary middle class standard British English. The author's personal (emotional and intellectual) stance provoked a sense of fear for readers. The author was against totalitarianism and dictatorship. He used special lexical items to provide a sense of fear for readers: p. 85 torture chamber. Several intensifiers, adjectives and adverbs were identified including violently, horrible, and deadly. There were frequent uses of narrative and descriptive structures to describe a dictatorial society: $\mathrm{p}$. 25 and in front of him there lay not death but annihilation. For social role relationship, the author put himself on a par with his addressees. The author acted as a narrator who told the story to the audience. He got readers involve in the story by using second single personal pronoun in an ordinary way without any authority. Although some informal words and idioms were used, the text did not contain technical and complicated word. The syntactic means applied were uses of personal pronouns and possessive adjectives in monologue, and dialogic parts: p. 15 always the eyes watching you..., and p. 235 we must meet again. The author most often talked about the Winston. That could suggest that the entire passage was described from Winston's point of view. Social attitude was consultative and informal. It was consultative and conversational because the text contained conversations and there was also participation between addressees. Therefore, no great social distance between author and audience could be seen. It was informal because there were contractions and informal lexical items such as slangs especially in the dialogues of characters of the novel. The lexical means applied here were use of colloquial, informal lexical items, use of idioms, use of gambits such as p. 75 the point is, p. 185 to tell you the truth, and use of lexical items indicating vagueness, for example kind of, sort of. The syntactic means were frequent use of single quotation marks ('...') for direct speeches, frequent use of contractions like p. 95 you'll have to..., and presence of elliptical structures: p. 145 any question? p. 135 why not? On MODE, the medium was complex because the text was written to be read as if spoken. The lexical means were use of colloquial lexical items and presence of interjections including p. $115 \mathrm{but}$ look! and p. 185 Ah, Smith! he said you too! The syntactic means were presence of elliptical structures, use of single quotation marks ('...') for marking direct speeches between characters, use of personal pronouns especially first and second personal pronouns, frequencies of contractions, frequencies of short coordinated clauses especially in dialogic parts linked with comma and and. There was also use of dash (-) rarely in narrator's speech and more frequently in conversations between characters to show a short pause in the speaker's ongoing speech: p. 215 but always - do not forget this, Winston - always there will be the intoxication. The text was etic because there were references to readers, links to the particular participants through the frequent uses of 
deictic personal pronouns, and involvement of addresser and addresses together. There were also redundancy through repetition and iconic linkage in the text. Participation was complex because there was a monologue with several instances of readers being directly addressed and with built-in dialogic parts. Predominance third person personal and possessive pronouns indicated narrative format of story. There were also other types of pronouns in dialogic and conversational parts especially first and second personal and possessive pronouns to indicate a direct conversational interaction inside the story. Frequent switches in the text between monologue format of the text and dialogic utterances between characters were seen as well. The text was predominantly etic drawing its readers into the text through ample uses of deictic pronouns: p. 205 we bring him to our side. GENRE was dystopian novel and science fiction.

\subsection{Statement of Function}

The function of Nineteen Eighty-Four mostly consisted of an interpersonal functional component. The ideational functional component was also implicitly present in the text, in that the text informed its readers about certain events involving the protagonist and the other characters depicted in the text. The author's intention was to warn people about totalitarian societies such as communist countries by providing a similar society which would exist in future. The interpersonal function was marked through the GENRE, since the author focused on the character of Winston who lived in a totalitarian society and described his thoughts, beliefs, and challenges. On the dimension of FIELD, the interpersonal function was present due to using colloquial lexical items, absence of technical academic terms, almost simple syntactic structures, and redundancy through repetition and iconic linkage. On TENOR, the consultative style level marked through informal lexical items, contractions, gambits, ellipses and repetitions supported interpersonal function. The MODE had also the interpersonal functional component because the medium of the text is 'written to be read as if spoken' and the participation was marked by frequent dialogic parts interspersed in the monologic framework.

\subsection{Comparison of Original and Translation}

On FIELD, there were lexical mismatches because the informality of words was reduced: thick negroid lips vs labhāȳ mutuvarim va bar āmadah. There were also syntactic mismatches because some of long sentences consisting of several subordinated clauses in the original text were translated into separate short sentences: p. $235 \mathrm{He}$ made a halfhearted attempt to catch up, then slowed down, turned, and made off in the opposite direction. vs ibtidā bā bì maylī sa'y kard bi ū birisad. ba'd qadam hā rā āhistah kard, charkhīd va dar jahati mukhālif bi rāh uftād. On TENOR, there were syntactic mismatches in social role relationship, since the second personal pronoun of you in monologue parts was translated differently in Persian, and instead impersonal pronouns 
such as insān, fard were used. As a result, interpersonal effectiveness and the involvement of readers in the story were reduced. Lexical mismatches were seen in social attitude since some of informal lexical items and idioms are markedly more formal in Persian translation. That widened the distance between the author and readers: p. 125 a lot of rubbish vs muhmal bäfîhā. On MODE, there were lexical mismatches in medium because some of colloquial and informal lexical items were translated to more formal lexical items in Persian (see lexical mismatches in TENOR).

\subsection{Overt Errors}

This section presents overt errors and their four subcategories of omissions, additions, substitutions, and breaches of the target language system. For each group one example is provided.

\subsubsection{Omissions}

Omissions refer to those missed parts in the translation text which have not been translated by the translator.

Table 1: Omissions.

\begin{tabular}{|c|c|c|}
\hline ST & TT & Explanation \\
\hline $\begin{array}{l}\text { p. } 65 \\
\text { And the tone of the } \\
\text { music changed too. }\end{array}$ & & $\begin{array}{l}\text { The translator missed the whole sentence. The overt } \\
\text { translation for this sentence is: Va tuni ăhang avaz } \\
\text { shud. }\end{array}$ \\
\hline
\end{tabular}

\subsubsection{Additions}

Additions occur when the translator adds extra elements in translation that do not match with the original text.

Table 2: Additions.

\begin{tabular}{lll}
\hline \multicolumn{1}{c}{ ST } & \multicolumn{1}{c}{ TT } & \multicolumn{1}{c}{ Explanation } \\
\hline p. 205 & Mā ū rā jisman va rūhan & jisman va rühan means \\
We bring him over to our & bi jibhayi khudimān & physically and mentally in \\
side, & mulhaq mīkunīm. & English. However, such \\
& & $\begin{array}{l}\text { words did not exist in the } \\
\text { original text. }\end{array}$ \\
\hline
\end{tabular}




\subsubsection{Substitutions}

This section contains errors which are due to either wrong selections or wrong combinations.

Table 3: Substitutions.

\begin{tabular}{|c|c|c|}
\hline ST & TT & Explanation \\
\hline $\begin{array}{l}\text { p. } 225 \\
\text { Also he knew that } \\
\text { somewhere or other } \\
\text { she was still alive } \\
\text { and needed his } \\
\text { help. }\end{array}$ & $\begin{array}{l}\text { Dar zimn } \\
\text { mīdānist } \bar{u} \\
\text { zindah ast va bi } \\
\text { kumaki vinstūn } \\
\text { nīyāz dārad. }\end{array}$ & $\begin{array}{l}\text { The subject of the sentence (he) refers to } \\
\text { Winston. Instead of using the name vinstīn } \\
\text { for adjective pronoun of his which distorts } \\
\text { the meaning of sentence, it is better to } \\
\text { translate the sentence like this: Dar zimn } \\
\text { mídannist } \bar{u} \text { zindah ast va bi kumakash nīyāz } \\
\text { dārad. }\end{array}$ \\
\hline
\end{tabular}

\subsubsection{Breaches of the Target Language System}

Breaches of the target language system are due to either ungrammaticality, that is, clear breaches of the target language system, or dubious acceptability, that is, breaches of the norm of usage. No instance of breaches of the TL system was found for ungrammaticality.

Table 4: Dubious acceptability.

\begin{tabular}{|c|c|c|}
\hline ST & TT & Explanation \\
\hline $\begin{array}{l}\text { p. } 65 \\
\text { He noticed that } \\
\text { both Aaronson } \\
\text { and Rutherford } \\
\text { had broken } \\
\text { noses. }\end{array}$ & $\begin{array}{l}\text { Vīnstūn daryāft } \\
\text { ki bīnīyi ārunsun } \\
\text { va rādirfūrd har } \\
\text { du shikastigī } \\
\text { dārad. }\end{array}$ & $\begin{array}{l}\text { The clause had broken noses was literally } \\
\text { translated by the translator. However, it is } \\
\text { not common in Persian to use the verb } \\
\text { dāshtan for shikastigì. Instead, this should } \\
\text { have been translated like this: Vinstūn } \\
\text { daryafft ki bintiyi ârunsun va rādirfürd } \\
\text { shikastah ast. }\end{array}$ \\
\hline
\end{tabular}

The frequency of occurrences of each type of overt errors was calculated as follows: 
Table 5: Frequency of occurrences of overt errors.

\begin{tabular}{ccc}
\hline Types of Errors & Frequency & Percentage \\
\hline Omissions & 76 & $25 \%$ \\
Additions & 34 & $11 \%$ \\
Substitutions & 196 & $63 \%$ \\
Breaches of the TL & 2 & $1 \%$ \\
System & & \\
Total & $\mathbf{3 0 8}$ & $\mathbf{1 0 0} \%$ \\
\hline
\end{tabular}

As it is shown in the Table 5, the largest group belongs to the category of substitutions with $63 \%$ and the smallest one is the breaches of TL system with only $1 \%$ of total errors. Between the two extremes, there are the category of omissions with $25 \%$, which is the largest category after the substitutions, and the category of additions with $11 \%$ of the total errors.

\section{Discussion and Conclusion}

According to House (1997), the overt kind of translation is needed for translation of literary works. Since Nineteen Eighty-Four is a literary work, therefore, in this study, the judgment for assessing the quality of translation was based on the criteria and standards defined for overt translation. That was why a considerable attention was paid for overt errors in the process of translation quality assessment. The analysis of original and translation revealed a number of mismatches along the dimensions of FIELD, TENOR, and MODE. These mismatches caused a change of the interpersonal functional component. There were also a large number of overt errors that affected the ideational component and the transmission of information. On FIELD, the long sentences in the ST were translated into several short sentences. As a result, a greater explicitness was made in translation. The interpersonal functional component was changed because the explicitness in translation directed readers' imagination and interpretation much more closely. On TENOR, the interpersonal functional component was changed because the second personal pronoun in the monologue parts of the original was substituted with the impersonal pronoun in the translation. Some of informal lexical items were translated more formal. Accordingly, the style level was changed in several instances and it became less informal as well. On MODE, there was a change in informality of the text which was similar to TENOR. Although, there were a number of dimensional mismatches in the translation, but GENRE remained unchanged.

The greater amount of loss was due to overt errors where a total number of 308 overt errors were identified. Out of this number, 196 errors (about 63\% of total number of errors) belonged to substitutions which constituted the largest group of overt errors. Omissions, additions, and the breaches of the TL system allocated 76, 34, and 2 errors 
(about $25 \%, 11 \%, 1 \%$ of total errors) respectively. The omissions and substitutions were assumed as major errors; while, additions and breaches of TL system were minor ones. Omissions were major errors because the translator intentionally or unintentionally missed and omitted several parts of the text that in most of the cases were not justifiable. Overt errors of substitutions were caused by wrong selections and wrong combinations in translation. This type of errors was due to the fact wrong equivalents were selected in translation. Additions used by the translator caused more clarification, explicitness, and redundancy in the text. In most of the cases, additions were neither necessary nor justifiable. Breaches of the TL system that had the lowest frequency of occurrences among the others did not have so much effect on the quality of translation.

To answer question one, the findings of the study including dimensional mismatches and overt errors should be taken into account. In other words, the translator's translation strategies could be revealed through the analysis of dimensional mismatches in general and analysis of overt errors in particular. According to the analysis, the strategies used by the translator were omissions, additions, substitutions, and use of cultural filter. However, the most frequent strategy used in translation was substitutions with 196 items. After substitution, omissions and additions were respectively the most frequent strategies used by the translator.

To answer question two of research and finally make the statement of quality, the criteria and features needed for overt translation should be borne in mind. It is obvious that in some parts of the text, the translator did not take account of denotative meanings of the words of the original. The author's style was not paid so much attention. In several cases, the translator manipulated the text which did not sound to be reasonable. In other words, it can be said that most of the text under the study was not translated overtly. Therefore, it can be concluded that based on the large number of overt errors including major errors such as omissions and substitutions, the criteria of overt translation were not fulfilled by the translator. Further, the application of the cultural filter to some parts of translation indicated changes at the levels of register (including dimensions of FIELD, TENOR, and MODE). There was more explicitness in the translation that affected the interpersonal functional component. Thus, the second-level functional equivalence required for overt translation was not reached. In addition, the visibility of the translator needed for overt translation was not seen in some parts of the translation. As a result, the Persian translation of Nineteen Eighty-Four by Balooch (2004) could not be assumed as an overt translation but reversely a covert translation.

The findings of this study can be compared to Gehrmann's (2011) research on quality assessment of Swedish translation of Tolkien's The Lord of the Rings. Like this study, Gehrmann analyzed textual profiles of both ST and TT and provided examples for them. He found a number of mismatches along the dimensions of tenor and field. $\mathrm{He}$ also detected the overt errors which were only caused by semantic additions and other types of overt errors were ignored. Unlike the current study, he did not calculate the frequencies of occurrences of each error. Finally, he concluded that the translation was 
a covert kind of translation. His conclusion mostly relied on analysis of dimensional errors.

The translation quality assessment of Nineteen Eighty-Four not only recognized the problematic areas including mismatches and errors in this particular translation but also revealed some facts about translation of literary works. This study showed what problems and difficulties a literary translator had to face with and what strategies he applied in the process of translation. The frequent strategies used by the translator in translation of such a literary work were omissions and substitutions which in most of the cases were not justifiable. A large number of errors found in this Persian translation of the popular literary work underline the significance of translation quality assessment for literary works in Iran. There can be Persian translations of many literary works that need to be reviewed and revised. Taking into account a theoretical framework as House's (1997) model in translation such can help translators detect and avoid mistakes and errors in translation process.

The findings of this study can be helpful for literary translators to get familiar with problems in translation of literary as well as strategies used to cope with such problems. Omissions and substitutions are the most frequent errors in Persian translation of Nineteen Eighty-Four. The editors of translation can also recognize the above-mentioned errors in literary translation and remove them in the process of reviewing and editing translation. The instructors and would-be translators can use the findings of the study in the process of learning and teaching translation. The major limitation of the study was this fact that House's (1997) model of TQA consisted of several different parts and it took into account almost all aspects of translation. Therefore, in this study, analyzing a number of pages took so much time and it became s a monotonous task. In this study, only the frequencies of occurrences of overt errors were computed. For further research, the frequencies of occurrences of dimensional mismatches can be calculated as well. Overt errors can be subdivided into more categories. The quality of translation of Nineteen Eighty-Four can be assessed by means of the other models of TQA and the results can be compared with those ones of this study. A similar study (translation quality assessment) can be done with literary texts in other languages. Additionally, other types of text with different genres can be assessed with House's model.

\section{References}

Baker, M. \& Saldanha, G. (2009). Routledge encyclopedia of translation studies $\left(2^{\text {nd }}\right.$ ed.). New York: Routledge.

Gehrmann, C. (2011). Translation quality assessment: A model in practice. Retrieved May 23, 2012, from http://urn.kb.se/resolve?urn=urn:nbn:se:hh:diva-16041

Hassan, B. A. (2011). Literary translation: Aspects of pragmatic meaning. Newcastle: Cambridge Scholars Publishing.

Hatim, B., \& Munday, J. (2004). Translation: An advanced resource book. New York: Routledge. 
Heidary, J., \& Haghani, A. (2009). Translation quality assessment: The examination of a literary text by baker's taxonomy. Retrieved August 02, 2012, from http://www.translationdirectory.com/articles/article2036.php

Hewson, L. (2011). An approach to translation criticism. Amsterdam: John Benjamins Publishing Co.

Hönig, H. (1998). Complexity, contrastive linguistics and translator training: Comments and responses. In C. Schaffner (Ed.), Translation and quality (pp. 83-89). Clevedon: Multilingual Matters Limited.

House, J. (1997). Translation quality assessment: A model revisited. Tubingen: Gunter Narr Verlag.

House, J. (2001). Translation quality assessment: Linguistic description versus social evaluation. Meta: Translators' Journal, 46, 243-257.

House, J. (2009). Translation. London: Oxford University Press.

Mohebbipour, M. (2010). The application of House's model to William Faulkner's 'The Sound and the Fury' and Its Persian translation by Saleh Hosseini. Retrieved May 16, 2012, from http://www.articlesbase.com/publishing-articles/the-application-of-houses-model-towilliam-faulkners-the-sound-and-the-fury-and-its-persian-translation-by-saleh-hosseini2937453.html

Munday, J. (2008). Introducing translation studies: Theories and application (2 $2^{\text {nd }}$ ed.). London: Routledge Publication.

Newmark, P. (1982). Approaches to translation. Oxford: Pergamon Institute of English.

Newmark, P. (1988). A textbook of translation. Hertfordshire: Prentice Hall International (UK) Ltd.

Nineteen eighty-four. (2012). Retrieved March 04, 2012, from http://en.wikipedia.org/wiki/Nineteen_Eighty-Four

Orwell, G. (1949). Nineteen eighty-four. Harmondsworth: Penguin Books Ltd.

Sadeghi, A. (2009). Translation quality assessment. Retrieved May 25, 2012, from http://www.articlesbase.com/languages-articles/translation-quality-assessment-tqa1120764.html

Thaicharoen, K. (2007). Translation quality: A study of Harry Potter: The philosopher's stone. Unpublished master's thesis, Srinakharinwirot University, Bangkok, Thailand.

Uraz, N. (2007). The criticism of the translations of Paul Auster's 'City of Glass'. Unpublished master's thesis, Hacettepe University Graduate School of Social Sciences, Ankara, Turkey.

Williams, M. (2001). The application of argumentation theory to translation quality assessment. Meta: Translators' Journal, 46, 326-344.

اورول، ج. (1383). 1984. ترجمه ح. ر. بلوت. تهران: گهبد، 288 صفحه. 